\title{
BENDROSIOS PRAKTIKOS SLAUGYTOJŲ DARBO SU CITOSTATIKAIS PROBLEMATIKA
}

\author{
Dalė Smaidžiūnienè $\dot{1}^{1}$ Lina Marcinkute் ${ }^{2}$ \\ ${ }^{1}$ Kauno kolegijos Medicinos fakultetas, ${ }^{2}$ Northway medicinos centras, Klaipeda
}

Raktažodžiai: slaugytojai, citostatikai, poveikis sveikatai, saugumo reikalavimų laikymasis.

\section{Santrauka}

Susirgimų onkologinèmis ligomis problematika daugelyje išsivysčiusių pasaulio šalių išlieka labai aktuali, gydant šias ligas vienas iš pagrindinių gydymo metodu yra chemoterapija, kuri veikia ne tik navikines ląsteles, bet ir sveikas. Pacientų gydymo chemoterapija procese visuomet dalyvauja slaugytojas: užsako, tinkamai transportuoja bei laiko, skiedžia, lašina tirpalus arba paduoda tabletes pacientams, sutvarko sistemas bei priemones po šių medikamentų panaudojimo. Slaugytojų darbas su citostatikais turi tam tikrą specifiką, kurią slaugytojai turi žinoti. Taip pat darbo su citostatikais metu reikia laikytis personalo ir paciento saugumo reikalavimų. Literatūroje dažniausiai nagrinejjami citostatikų šalutiniai poveikiai pacientams, tyrimų, rodančių, kaip tai veikia bendrosios praktikos slaugytojų sveikatą, atliekama nedaug. Tyrimo tikslas: atskleisti darbo su citostatikais problematiką saugumo reikalavimų laikymosi bei poveikio bendrosios praktikos slaugytojų ir būsimujjų slaugytojų sveikatai kontekste.

Straipsnyje analizuojami trijų tyrimų su identišku tyrimo objektu rezultatai. Tyrimai atlikti 2010, 2014, 2016-ais metais, juose dalyvavo X ir Y miestuose dirbantys 249 slaugytojai. Papildomai buvo apklausti visi $\mathrm{X}$ miesto $\mathrm{N}$ aukštosios mokyklos, pirmos pakopos bendrosios praktikos slaugos studijų studentai, kuriems profesinès veiklos praktikų metu teko dirbti su citostatikais.

Tyrimo išvados. Skiedžiant citostatikus, slaugytojai dažniausiai ịsijungia traukos spintą, tačiau darbo vietose vis dar trūksta kokybiškų asmeninių apsaugos priemonių arba slaugytojai jų nenaudoja. Tyrimas atskleide, kad pasitaiko atvejų, kai citostatikai skiedžiami procedūriniame kabinete arba kitoje tam nepritaikytoje patalpoje. Pagrindinis specifiškas ne- pageidaujamas reiškinys slaugytojams skiedžiant citostatikus - metalo skonis burnoje, o bendrosios praktikos slaugos studijų studentams: galvos skausmas ar svaigimas, pykinimas, odos paraudimas, niežejjimas. Bendrosios praktikos slaugos studentai kaip pagrindinę problemą profesinès veiklos praktikų metu išsakè - instruktažo studentams nebuvimą ir netinkamus profesinius pavyzdžius, tokius kaip: pačių slaugytojų savisaugos bei darbo su citostatikiais saugumo reikalavimų nesilaikymas.

\section{İvadas}

Susirgimų onkologinèmis ligomis problematika daugelyje išsivysčiusių pasaulio šalių išlieka labai aktuali. Pasaulio sveikatos stebejjimo tarnybos (GHO) duomenimis, 2015 metais iš $56,4 \mathrm{mln}$. mirčiu pasaulyje $39,5 \mathrm{mln}$., arba 70 proc., buvo susiję su neinfekcinėmis ligomis: pirmoje vietoje - širdies bei kraujagyslių ligos, antroje - vėžys. Iš visų 2015 metais pasaulio stebejjimo tarnybos užregistruotų mirčių atvejų mirusių nuo vėžio žmonių buvo $8,8 \mathrm{mln}$. arba 22 proc. [8]. Higienos instituto Sveikatos informacijos centro duomenimis, $2016 \mathrm{~m}$. Lietuvoje gyventojų ligotumas onkologinèmis ligomis sudare 8,2 proc. suaugusiųjų ir 1,6 proc. vaikų 100 gyventojų. Mirtingumas Lietuvoje nuo véžio 2016 m. -8197 atvejai, tai sudaro 19,9 proc. visų mirties atvejų $[3,4]$.

Atsižvelgiant ị onkologinių ligų didèjimo tendenciją, būtina anksti diagnozuoti ligą, užkirsti kelią vėžio vystymuisi, taikyti efektyvius gydymo metodus. Gydant onkologines ligas taikomi ịvairūs gydymo metodai, tačiau vienas iš pagrindinių vėžio gydymo metodų išlieka - chemoterapija, kuri veikia ne tik navikines ląsteles, tačiau ir sveikas, greitai proliferuojančias normalių audinių ląsteles [11]. Vèžiui gydyti naudojami chemoterapiniai vaistiniai preparatai nepageidaujamas reakcijas gali sukelti ir kontaktą su vaistu turinčiam medicinos personalui. Ne visose ligoninèse įdiegtas centralizuotas citostatikų skiedimas, todèl bendrosios praktikos slaugytojai, kontaktuodami su citostatikais, patiria šalutinị 
vaistų poveikị. Nuo 2017 -ụjų birželio mėnesio Lietuvos sveikatos mokslų universiteto Kauno klinikose pradètas centralizuotas vaistų skiedimas, kai vaistai skiedžiami specialiose traukos spintose, čia laminarinis oro srautas apsaugo darbuotoją nuo bet kokio kontakto su vaistu. I šias patalpas farmacijos specialistai patenka apsirengę sterilią aprangą: specialią avalynę, beplaušius kombinezonus, dèvi dvi poras sterilių pirštinių, iš kurių vienos skirtos darbui su citostatikais, chirurginę kaukę ir galvos apdangalą. Šioje ligoninèje taikomos naujos technologijos standartizuoja procesus, užtikrina aukštą onkologinès pagalbos lygi bei padidina pacientų ir darbuotojų saugumą [10].

Literatūroje dažniausiai nagrinèjamas citostatikų šalutinis poveikis pacientų sveikatai, o tyrimų, rodančių, kaip citostatikai veikia slaugytojų sveikatą, yra nedaug. Šią problematiką Lietuvoje nagrinėjo V. Januškevičius. Jo atliktų tyrimų metu 7,8 proc. respondentų nurodè dirbantys su citostatikais. Sąsajų tarp šiu preparatų vartojimo ir vaistų nepageidaujamo poveikio nebuvo aprašyta, tačiau šio autoriaus teigimu, 42,8 proc. slaugytojų savo darbo aplinkoje susiduria su cheminiu užterštumu, dẻl to slaugytojams dažniausiai sukeliamas nepageidaujamas poveikis -odos pažeidimai, pasireiškiantys sutrūkinèjusia oda, niežèjimu, paraudimu, bėrimu, o 7 iš 10 respondentų, dirbančių su vaistinèmis medžiagomis, skundžiasi sloga, greitu nuovargiu, pusè patiria dažnus galvos skausmus [5]. Kito tyrimo rezultatai parodé, kad ketvirtadalis slaugytojų, skiesdami citostatikus, nedèvi jokių apsauginių pirštinių, tik dešimtadalis dèvi apsaugines chirurgines kaukes ir apsauginị vienkartinị chalatą, o rečiausiai naudojamos vienkartinès prijuostès $(5,8$ proc.), apsauginiai akiniai (7,7 proc.) arba veido skydelis (6,3 proc.). Dirbantys su citostatiniais preparatais slaugytojai blogiau vertina savo sveikatos būklę nei tie, kurie neturi kontakto su šiais vaistais [9].

2012 metais Irane vykdyto tyrimo metu dalyvavo 63 slaugytojai, dirbantys chemoterapijos skyriuje. Maždaug 60 proc. slaugytojų naudojosi visomis asmens apsaugos priemonemis. Visose patalpose buvo oro kondicionieriu ventiliacijos sistemos, tačiau jos nebuvo standartinès. Visi tyrimo dalyviai nurode žinių apie darbą su citostatikais trūkumą. Šio tyrimo rezultatai taip pat parodé, kad slaugytojams, dirbantiems su citostatikais, galvos skausmas (65 proc.) ir odos alerginès reakcijos (64 proc.) pasireiškia dažniau negu kiti ūmūs nepageidaujami reiškiniai, pavyzdžiui, galvos svaigimas, pykinimas, niežulys [6].

Pastaraisiais metais slaugytojų darbo sąlygos, aprūpinimas savisaugos priemonèmis gerejo, tačiau darbo su citostatikais specifika nuolat reikalauja slaugytojų žinių, neskubant atlikti šias procedūras bei laikytis saugos reikalavimų, o tai igyvendinti ne visuomet pavyksta dèl didelių darbo krūvių, kuriuos sąlygojo slaugytojų Lietuvoje trūkumas. Siekiant spręsti šią problemą reikia plèsti centralizuotą šių vaistų skiedimą, mokyti slaugytojus darbo su citostatikais ypatumu bei skatinti neskubèti ir laikytis saugumo reikalavimų.

Tyrimo tikslas: atskleisti darbo su citostatikais problematiką saugumo reikalavimų laikymosi bei poveikio bendrosios praktikos slaugytojų ir būsimųų slaugytojų sveikatai kontekste.

\section{Tyrimo medžiaga ir metodai}

2010, 2014, 2016-aisiais metais atlikta N aukštosios mokyklos trijų bendrosios praktikos slaugos studentų bakalauro diplominių darbų apie slaugytojų darbo su citostatikais tiriamosios veiklos analizè, esant identiškam tyrimo objektui. Tyrimai atlikti. Jais buvo siekiama išsiaiškinti, su kokiomis problemomis susiduria bendrosios praktikos slaugytojai, dirbdami su citostatikais, bei sužinoti slaugytojų nuomonę apie šių vaistų šalutinius poveikius pačių slaugytojų sveikatai. Kiekybinio tyrimo kontingentą sudare 249 slaugytojai, dirbantys Lietuvos X ir Y ligoninèse. Tyrimo metodas - anketinè apklausa raštu. Apklaustų slaugytojų amžiaus vidurkis buvo nuo 22 iki 63 metų, darbo stažas svyravo nuo 2 mèn. iki 42 metų. 2016-ujų metų tyrimui atlikti buvo gautas Lietuvos sveikatos mokslų universiteto Bioetikos centro leidimas ( $\mathrm{Nr}$. BEC - KK (B). 2010 ir 2016 metais tyrimai atlikti X miesto ligonineje, 2014 metais atliktas tyrimas $\mathrm{X}$ miesto ir Y miesto ligoninèse. Visi respondentai tyrimuose dalyvavo laikantis savanoriškumo, anonimiškumo, konfidencialumo ir pagarbos principų. Tiriamujų atranka - tikimybinè paprasta. Siekiant išsiaiškinti, su kokiomis problemomis susiduria bendrosios praktikos slaugytojai, dirbdami su citostatikais, buvo pasirinkti visi slaugytojai, kurie savo darbe kontaktuoja su šiais preparatais. Dviejų tyrimų duomenys nagrinèti „,SPSS 21.0“ ir vieno tyrimo duomenys analizuoti „Microsoft Office Excel" programomis.

2017 gegužès mèn. atliktas kokybinis tyrimas. Buvo apklausti visi $\mathrm{X}$ miesto $\mathrm{N}$ aukštosios mokyklos pirmos pakopos bendrosios praktikos slaugos studijų studentai. Iš visų tuo metu besimokančių pirmo-ketvirto kurso bendrosios praktikos slaugos studentų, tik 18 nurodė profesinès veiklos praktikų metu kontaktavę su citostatikais. Studentų buvo prašoma atsakyti, kokias problemas įžvelge praktikos vietose dirbdami su citostatikais, koks šalutinis šių medikamentų poveikis pasireiškè studentų sveikatai, ar slaugytojai laikosi saugumo reikalavimų, kurie yra reglamentuoti darbo instrukcijose?

\section{Tyrimo rezultatai ir aptarimas}

Tyrimo rezultatai buvo analizuojami trimis aspektais: 1. Ivertinta, kaip slaugytojai, skiesdami citostatikus, laikosi 
saugumo reikalavimų. 2. Nustatyta dažniausiai pasireiškiantys šalutiniai reiškiniai darbo su citostatikais kontekste. 3. Išskirtos $\mathrm{X}$ miesto $\mathrm{N}$ aukš-

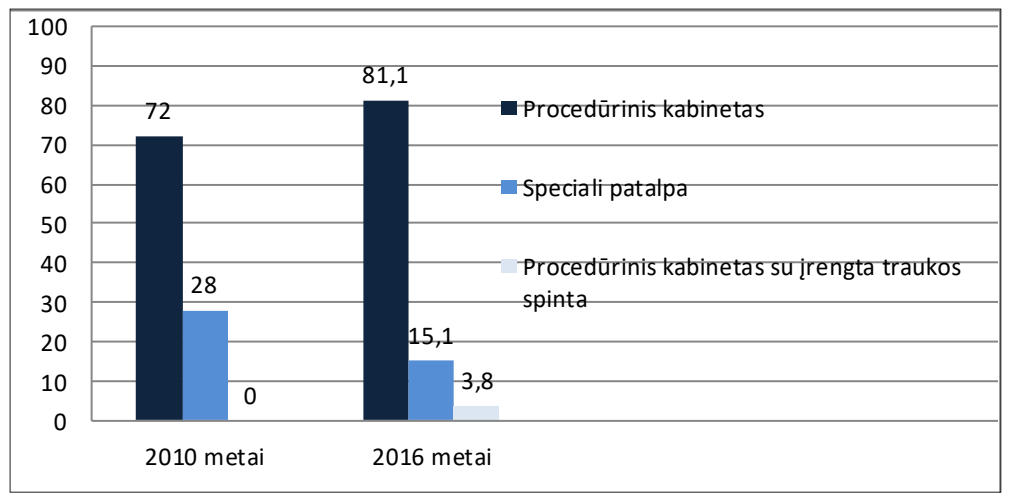

1 pav. Citostatikų skiedimo vieta 2010 ir 2016- aisiais metais

1 lentelè. Bendrosios praktikos slaugytojų savisaugos priemonių naudojimo ir saugumo reikalavimų laikymosi rodiklių palyginimas skirtingais metais, išreikštas procentais

\begin{tabular}{|c|c|c|c|}
\hline Saugumo priemonių naudojimas & $\begin{array}{l}2010 \text { metai } \\
(N=50)\end{array}$ & $\begin{array}{l}2014 \text { metai } \\
(N=146)\end{array}$ & $\begin{array}{l}2016 \text { metai } \\
(\mathrm{N}=53)\end{array}$ \\
\hline $\begin{array}{l}\text { Traukos spintos ijungimas, skiedžiant } \\
\text { citostatikus }\end{array}$ & 56,0 & 80 & 83,0 \\
\hline Vienkartinès kaukès naudojimas & 78,0 proc. & 49,5 proc. & 60,4 proc. \\
\hline Vienkartinių pirštinių naudojimas & 97,0 proc. & 94,5 proc. & 88,7 proc. \\
\hline $\begin{array}{l}\text { Vienkartinio chalato (prijuostès) nau- } \\
\text { dojimas }\end{array}$ & 48,0 proc. & 64,0 proc. & 30,2 proc. \\
\hline $\begin{array}{l}\text { Apsauginių akinių (skafandro) naudo- } \\
\text { jimas }\end{array}$ & 9,0 proc. & 22,0 proc. & 41,5 proc. \\
\hline
\end{tabular}

2 lentelè. Dažniausi nurodomi nepageidaujami reiškiniai, pasireiškę respondentams skirtingais tyrimo metais

\begin{tabular}{|c|c|c|c|}
\hline $\begin{array}{l}\text { Tyrimo metai } \\
\text { Nepageidau- } \\
\text { jami reiškiniai }\end{array}$ & $\begin{array}{l}2010 \text { metai } \\
(\mathrm{N}=\mathbf{5 0})\end{array}$ & $\begin{array}{l}2014 \text { metai } \\
(\mathrm{N}=146)\end{array}$ & $\begin{array}{l}2016 \text { metai } \\
(\mathrm{N}=53)\end{array}$ \\
\hline Dusulys & 48,0 proc. & 27,0 proc. & 22,4 proc. \\
\hline Gerklų spazmai & 72,0 proc. & 10,5 proc. & 24,5 proc. \\
\hline Metalo skonis burnoje & 87,0 proc. & 59,5 proc. & 77,4 proc. \\
\hline $\begin{array}{l}\text { Deginimas veide, aplink lūpas, } \\
\text { smakrą }\end{array}$ & 80,0 proc. & 51,5 proc. & 77,4 proc. \\
\hline Veido odos alerginès reakcijos & 69,0 proc. & 71,5 proc. & 77,4 proc. \\
\hline Rankų odos alerginès reakcijos & 87,0 proc. & 77 proc. & 83,0 proc. \\
\hline Akių perštėjimas & \multirow{4}{*}{$\begin{array}{l}\text { Šio tyrimo metu } \\
\text { nurodytu nepa- } \\
\text { geidaujamų reiš- } \\
\text { kinių slaugytojai } \\
\text { nepažymejo }\end{array}$} & 65,0 proc. & 77,4 proc. \\
\hline Padidèjęs plaukų slinkimas & & 63,5 proc. & 50,9 proc. \\
\hline Nagų lūžinèjimas & & 56,5 proc. & 71,7 proc. \\
\hline Galvos skausmas & & 33,0 proc. & 50,9 proc. \\
\hline
\end{tabular}

tosios mokyklos pirmos pakopos bendrosios praktikos slaugos studentu pastebetos problemos profesinès veiklos praktikos metu, dirbant su citostatikais.

Ligoninèse LR sveikatos apsaugos ministro įsakymu patvirtinti procedūrų aprašai, kuriais turi vadovautis slaugytojos, dirbdamos su citostatikais. Kaip pavyzdį paėmėme Lietuvos sveikatos mokslų universiteto Kauno klinikų (LSMU KK) darbo instrukciją, kurioje teigiama, kad citostatikai ruošiami ịsijungus traukos spintą, pasitiesus vienkartini paklotą, dirbama apsirengus vienkartinį chalatą, užsidejjus vienkartinę kepurę, apsauginius akinius, vienkartinę kaukę (arba kaukę su apsauginiu skydeliu), vienkartines diagnostines pirštines. LSMU KK darbo instrukcijoje nurodoma, kad dirbant su chemopreparatų tablečių forma negalima liesti chemopreparatų (tablečių, kapsulių) be pirštinių, kurios naudojamos per $o s$, kapsulès ir tabletès iš pakuotès imamos pincetu. Kapsulę ar tabletę išèmus iš flakonèlio, ją būtina ịdèti ị taurelę [1].

Bendrosios praktikos slaugytojų saugumo reikalavimo principų laikymosi tendencijos atsispindi 1 lentelèje. Tyrime dalyvavusiems respondentams buvo pateikti teiginiai, susiję su apsauginių priemonių naudojimu darbo metu. Iš pateiktų duomenų galima daryti prielaidą, kad technologijoms tobulejjant, skyriuose, kuriuose slaugytojai dirba su citostatikais, yra ịrengtos traukos spintos ir slaugytojai, skiesdami citostatikus, jas įsijungia. Tačiau 2016-aisiais metais tyrimas atskleidè, kad slaugytojai patys supranta, kad tik traukos spintos nepakanka, norint apsisaugoti nuo nepageidaujamų reiškinių: „,chemoterapiniai vaistai turètų būti paruošti (atskiesti) ir nereikètų skyriuje skiesti, skaičiuoti dozių (kas yra atliekama kitose šalyse)“. Tyrimas parodè, kad dauguma (per 80 proc.) respondentų dèvi apsaugines vienkartines diagnostines pirštines, kurios apsaugo rankas nuo tiesioginio sąlyčio su cheminėmis medžiagomis. Lyginant tyrimus, atliktus skirtingais metais, pastaraisiais, 2016-aisiais metais, didesne slaugytojų dalis (41,5 proc.) dèvi apsauginius akinius ar apsauginį skafandrą. Taip pat 2016-uјų atliktas tyrimas atskleidžia, kad darbo vietose trūksta pakankamo kokybiškų medicininių priemonių 


\section{6}

kiekio, nurodo kad trūksta: „Geresnės kokybės infuzinių sistemų, kadangi esamos yra nekokybiškos, prateka skysčiai su chemopreparatais","Trūksta geresnès kokybès švirkštų, stipresnių pirštinių (kadangi turimos greit suplyšta)“.

Siekiant išsiaiškinti, kokius šalutinius reiškinius bendrosios praktikos slaugytojams gali sukelti citostatikai, tikslingiausia buvo sužinoti, kur slaugytojai skiedžia citostatikus (1 pav.). Toks klausimas buvo pateiktas 2010 ir 2016 - aisiais metais. Pastaraisiais metais daugiau nei aštuoni dešimtadaliai (81,1 proc.) respondentų citostatikus skiedžia procedūriniame kabinete arba kitoje tam nepritaikytoje patalpoje. Lyginant 2010 ir 2016 metus, respondentų skaičius, kuris rodo, kad citostatikai skiedžiami specialioje patalpoje, sumažèjo daugiau nei dešimtadaliu (2016-aisiais 15,1 proc. respondentų nurodè, kad yra speciali patalpa citostatikams skiesti). Mažiau nei penktadalis ( 3,8 proc.) nurodè citostatikus skiedžiantys procedūriniame kabinete, kuriame ịrengta traukos spinta, tačiau šioje patalpoje gali būti skiedžiami ir kiti vaistai, pavyzdžiui, antibiotikai.

Nepaisant griežtu chemopreparatų laikymo, darbo su jais taisyklių, atitinkamos ịrangos tobulinimo ligoninèse, nedideli citostatikų kiekiai randami ant paviršių, ore bei stebimi nepageidaujami reiškiniai tiems asmenims, kurie dirba tose patalpose, ar tiesiogiai kontaktuoja su vaistais [7]. Kai kurie chemopreparatai lengvai prasiskverbia pro nepažeistą odą, patenka ị poodžio riebalų sluoksnị, o iš ten lètai ị kraują [5]. Šalutini chemopreparatų poveikị darbuotojai gali patirti šiais būdais: kai chemopreparatai pristatomi ị skyrių, išpakuojant, saugant vaistų buteliukus, transportuojant panaudotas citostatines atliekas, ruošiantis atlikti infuzijas (kitose užsienio šalyse chemopreparatų infuzijas pacientams paruošia centralizuotai, tačiau Lietuvoje dažniausiai patys slaugytojai ruošia infuzijas), dirbant su pacientais (dalis šių nepakitusių vaistų išsiskiria kartu su vèmalais, išskyromis, prakaitu), valant darbastalius, klojant pacientų lovą ir kt. [2].

2 lentelèje matyti pagrindiniai šalutiniai reiškiniai, kuriuos nurodè tyrime dalyvavę bendrosios praktikos slaugytojai. Visų trejų metų tyrimai patvirtino slaugytojų patiriamą specifiškiausią nepageidaujamą poveikį, kuris pasireiškia skiedžiant citostatikus - burnoje jaučiamą metalo skonį. Kiti nepageidaujami reiškiniai, kuriuos nurode respondentai: deginimas veide, aplink lūpas, smakrą, veido ir rankų odos alerginès reakcijos gali pasireikšti kontaktuojant su kitomis cheminèmis medžiagomis, pavyzdžiui, dezinfekci-

3 lentelè. X miesto $\mathrm{N}$ aukštosios mokyklos, pirmos pakopos bendrosios praktikos slaugos studentų subjektyvia nuomone, išryškejjusios problemos profesinès veiklos praktikos metu

\begin{tabular}{|c|c|c|}
\hline Kategorija & Autentiški bendrosios praktikos slaugytojų pasisakymai & $\begin{array}{l}\text { Kartotiniü } \\
\text { skaičius } \\
(\mathbf{N}=8)\end{array}$ \\
\hline $\begin{array}{l}\text { Instruktažo nebuvimas ben- } \\
\text { drosios praktikos slaugos stu- } \\
\text { dentams }\end{array}$ & $\begin{array}{l}\text { „Niekas nepaaiškino apie chemopreparatų kenksmingumą. Nesilaiko } \\
\text { savisaugos reikalavimų nei pačios slaugytojos, nei mums paaiškina“; } \\
\text { „Pačioje pradžioje iš personalo trūko informacijos apie chemopreparatų } \\
\text { skiedimo metu sukeltus šalutinius poveikius, o vaistus skiedėme tiesiog } \\
\text { procedūriniame, nieks nesakė apie traukos spintą“; } \\
\text { „<..> nebuvau instruktuota. Buvo pasakyta lyg tarp kitko, kad įsijung- } \\
\text { čiau traukos spintą. Apie apsaugos priemones (pirštines, kaukes) nebuvo } \\
\text { kalbama“ }\end{array}$ & 11 \\
\hline $\begin{array}{l}\text { Saugumo reikalavimų nesilai- } \\
\text { kymas }\end{array}$ & $\begin{array}{l}\text { „Nesilaiko. Gal vyresnės slaugytojos nežino. Mums kažkiek paaiškino } \\
\text { jaunos, tik ką baigusios, kurios nebuvo mūsų mentoremis“; } \\
\text { „Kai kurios slaugytojos dalinai laikėsi reikalavimų, ir man liepè taip pat. } \\
\text { Kitos laikėsi, bet man nieko nepasakè. Kitos visai nesilaikė saugumo } \\
\text { reikalavimų“. }\end{array}$ & 5 \\
\hline $\begin{array}{l}\text { Didelis skiedžiamų citostatikų } \\
\text { kiekis vienu metu }\end{array}$ & „Reikejjo atskiesti dideli citostatikų kiekị vienu metu“ & 3 \\
\hline $\begin{array}{l}\text { Asmeninių apsaugos priemo- } \\
\text { nių stoka }\end{array}$ & $\begin{array}{l}\text { „Nèra pakankamai apsaugos priemonių“; } \\
\text { „Neužtekdavo priemonių - pirštinių, kaukių, apsiaustų, kepurių“ }\end{array}$ & 3 \\
\hline Praktinių igūdžių trūkumas & $\begin{array}{l}\text { „<...> praktinių ịūdžių trūkumas, apsitaškymas citostatikais“" } \\
\text { „Keisdama lašelinę apsipyliau rankas, nieks nepasakè, kad pavojinga, } \\
\text { buvau be pirštinių. Ploviau rankas vandenyje ir nieko nebuvo“ }\end{array}$ & 3 \\
\hline $\begin{array}{l}\text { Reikalavimų neatitinkanti trau- } \\
\text { kos spinta }\end{array}$ &,$<\ldots>$ netinkama traukos spinta (nesandari)“ & 2 \\
\hline
\end{tabular}


nėmis priemonėmis, dėvint lateksines pirštines ar skiedžiant antibiotikus. Akių perštėjimo, padidejjusio plaukų slinkimo, nagų lūžinejjimo, galvos skausmo 2010 metais atlikto tyrimo metu slaugytojai neįvardijo, nors pastaraisiais metais bene daugiau nei pusè slaugytojų nurodè patiriantys šiuos nepageidaujamus reiškinius.

Kauno miesto $\mathrm{N}$ aukštosios mokyklos, pirmos pakopos bendrosios praktikos slaugos studentai, profesinių veiklos praktikų metu dirbę su citostatikais, nurodè, kokios problemos susijusios su citostatikų skiedimu, vyravo jų praktikos vietose. Kadangi tyrimas buvo kokybinis, studentai galejo išsakyti po kelias problemas, kurias įžvelgè praktikos metu. Kaip pagrindinę problemą, didesnè dalis apklausoje dalyvavusių studentų išskyrè instruktažo nebuvimą: „Pačioje pradžioje iš personalo trūko informacijos apie chemopreparatų skiedimo sukeltus šalutinius poveikius“". Keletas respondentų nurodè, kad slaugytojai patys nesilaiko saugumo reikalavimų, jie daro prielaidą, kad „vyresnès slaugytojos jų nežino. Mums (studentams) kažkiek paaiškino jaunos, tik ką baigusios slaugytojos, kurios nebuvo mūsų mentorèmis“. Keli studentai teige, kad slaugytojai neatsižvelgdavo ị tai, jog studentams reikia perduoti patirti, suteikti visapusišką studento apsaugą: „reikejjo atskiesti didelị citostatikų kiekị vienu metu“, „keisdama lašelinę apsipyliau rankas, nieks nepasake, kad pavojinga, buvau be pirštinių“. Studentų apklausos metu išryškejjo ir priemonių trūkumo problemos: „neužtekdavo priemonių - pirštinių, kaukių, apsiaustų, kepurių“" ( 3 lentelè).

Atsakydami ị klausimą, kokie citostatikų šalutiniai reiškiniai pasireiškė bendrosios praktikos slaugos studijų studentams, dalis respondentų nurodè, kad skiesdami šiuos vaistus patyrè: galvos svaigimą, pykinimą, odos paraudimą, niežèjimą, rankų odos šiurkštumą, galvos ir akių skausmą. Keletas bendrosios praktikos slaugos studijų studentų nurodė, kad šalutinis citostatikų poveikis jiems nepasireiškè.

\section{Išvados}

1. Technologijų tobulèjimas sudaro geras prielaidas slaugytojoms saugiai dirbti skiedžiant citostatikus, tačiau patys slaugytojai ne visuomet ịsijungia traukos spintas ir naudojasi savisaugos priemonèmis.

2. Keleto metų tyrimai atskleidè, kad slaugytojai, dirbdami su citostatikais, patiria nepageidaujamus jų poveikius. Dažniausi nepageidaujami poveikiai, pasireiškiantys slaugytojams darbo su citostatikais metu, yra metalo skonis burnoje, deginimas veide, aplink lūpas, smakrą, veido odos alerginès reakcijos, akių perštejimas, rečiau pasireiškia galvos skausmai, dusulys, gerklų spazmai ir kt. Kai kuriose darbo vietose nėra specialiai citostatikų skiedimui pritaikytų patalpų, kai kur trūksta ir savisaugos priemonių arba kartais patys slau- gytojai jų nenaudoja.

3. Bendrosios praktikos slaugos studentai profesinès veiklos praktikos metu dèl kontakto su citostatikais nurodè patyrę galvos svaigimą, pykinimą, odos paraudimą, niežèjimą. Būsimujų slaugytojų praktikų metu, skiriant užduotị studentui dirbti su citostatikais, reikètų prieš tai ji informuoti apie darbo su citostatikais ypatumus, kadangi ne visų kursų studentai žino darbo su šiais preparatais specifiką. Pačios slaugytos mokydamos studentą turètų rodyti gerus profesinius pavyzdžius: laikytis saugumo reikalavimų, naudoti traukos spintas ir reikiamas savisaugos priemones.

\section{Literatūra}

1. Citostatinių preparatų ruošimas, suleidimas, sugirdymas. LSMU KK Darbo instrukcija. Kaunas, 2001.

2. Europos Komisija (2013). Rizika darbuotojų sveikatai ir saugai sveikatos priežiūros sektoriuje. Liuksemburgas, 2013; http:// www.vdi.lt/AtmUploads/RizikaDSSsveikatosprieziura.pdf

3. Higienos instituto Sveikatos informacijos centras. Lietuvos gyventojų ligotumas $2016 \mathrm{~m}$. http://sic.hi.lt/php/serg14. php?dat_file=serg14.txt

4. Higienos instituto Sveikatos informacijos centras. Mirtingumas pagal priežastis ir amžiaus grupes $2016 \mathrm{~m}$. http://sic.hi.lt/php/ dm6.php?dat_file $=$ dem6.txt

5. Januškevičius V. Slaugytojų darbo sąlygų ir sveikatos sąsajų vertinimas. $2006 \mathrm{~m}$. http://www.lvb.lt/primo_library/libweb/ action/dlDisplay.do?vid=LSMU\&docId=ELÄBAETD 17747 28\&fromSitemap=1\&afterPDS=true

6. Momeni M. How do nurses managet heir occupational exposure to cytotoxic drugs? A descriptive survely in chemotherapy settings, Shiraz, Iran. The International Journal Of Occupational And Environmental Medicine 4(2):102-106. http://www. theijoem.com/ijoem/index.php/ijoem/article/view/198/363

7. Sorsa M, Hämeilä M, Järviluoma E. Handling anticancer drugs: from hazard identification to risk management? PMID: 17119240

http://onlinelibrary.wiley.com/doi/10.1196/annals.1371.008/ abstract;jsessionid $=072 \mathrm{~F} 3 \mathrm{C} 269 \mathrm{D} 054 \mathrm{~F} 1 \mathrm{C} 6637 \mathrm{DC} 810 \mathrm{~F} 6 \mathrm{FB} 3$ AB.f03t03

8. World Health Organization. Cancer; 2017. http://www.who. int/cancer/en/

9. Brazienè J. Medikų, dirbančių su onkologiniais ligoniais, darbo sąlygų ir nusiskundimų sveikata sąsajos, 2008.

http://vddb.library.lt/fedora/get/LT-eLABa-0001:E.02 2008 Ｄ_20080616_145420-35201/DS.005.0.01.ETD

10. Kauno kliniku informacija (2017) Kauno klinikose pradètas centralizuotas vaistų skiedimas Prieiga per internetą: http:// www.vlmedicina.lt/lt/kauno-klinikose-pradetas-centralizuotasvaistu-skiedimas

11. Valuckas K. P., Aleknavičienė B. Piktybinių lokalizacijų piktybinių navikų diagnostikos ir gydymo pagrindai, Vilnius, 2004. 
THE PROBLEM OF GENERAL PRACTICE NURSES WORK WITH CYTOSTATIC DRUGS

\section{Smaidžiūnienė, L. Marcinkutè}

Key words: nurses, cytostatics, cytostatic drugs, influence on health, following safety demands.

Summary

The problem of oncological diseases remains very relevant in developed countries. One of the main treatment methods for this is chemotherapy, which affects not only tumor cells but also the healthy ones.

A nurse participates during the whole chemotherapy treatment process: orders, transports, keeps, dilutes and pours solutions, gives medicine and arranges systems and means after that. Work with cytostatic drugs has specific nature which nurses must be aware about. It is also very important to follow safety demands. Literature usually analyses the side effects of cytostatic drugs but there are only a few researches about how does it effect the health of general practice nurses.

The aim of this article is to reveal the problem of working with cytostatics in the context of folowing safety demands and effect on general practice nurses or future nurses health.

This article analyses the results of three different researches with one same object. Researches were carried out in 2010, 2014 and 2016, 249 nurses from cities X and Y participated. In addition, all students from educational institution $\mathrm{N}$, who studied general nursing practice for the first year and who worked with cytostatic drugs during their professional practice activity, where also questioned.

Study Results. During cytostatics dilution process nurses usually switch on gravitation closet but their working place still lacks qualitative safety measures or nurses just do not use them. The research showed that there are some cases when cytostatics are diluted in procedure room or in other inapplicable premises.

During cytostatics dilution process the main unwanted side effect for nurses is metallic taste in their mouth, while for general practice students - headache, dizziness, feeling sick, rash and scabbiness. General practice students excluded two main problems of professional activity practice - lack of instruction and wrong professional skills, such as no self-preservation and not following safety demands when working with cytostatic drugs.

Correspondence to: dale.smaidziuniene@go.kauko.lt

Gauta 2017-10-30 